\title{
A spatial and temporal drought risk assessment of three major tree species in Britain using probabilistic climate change projections
}

\author{
Michal Petr • Luc G. J. Boerboom • \\ Anne van der Veen • Duncan Ray
}

Received: 30 September 2013 / Accepted: 26 March 2014 / Published online: 25 April 2014

C) The Author(s) 2014. This article is published with open access at Springerlink.com

\begin{abstract}
Probabilistic climate data have become available for the first time through the UK Climate Projections 2009, so that the risk of change in tree growth can be quantified. We assessed the drought risk spatially and temporally using drought probabilities calculated from the weather generator data and tree species vulnerabilities using Ecological Site Classification model across Britain. We evaluated the drought impact on the potential yield class of three major tree species (Picea sitchensis, Pinus sylvestris, and Quercus robur), which cover around $59 \%$ (400,700 ha) of state-managed forests, across the lowlands and uplands. We show that drought impacts result mostly in reduced tree growth over the next 80 years when using B1, A1B, and A1FI IPCC emissions scenarios, but varied spatially. We found a maximum reduction of $94 \%$ but also a maximum increase of $56 \%$ in potential stand yield class in the 2080s from the baseline climate (1961-1990). Furthermore, potential production over the state-managed forests for all three species in the $2080 \mathrm{~s}$ is estimated to decrease due to drought by $42 \%$ in the lowlands and by $32 \%$ in the uplands in comparison to the baseline climate. Our results reveal that potential tree growth and forest production on the state-managed forests in Britain is likely to reduce, and indicate where and when adaptation measures are required.
\end{abstract}

Electronic supplementary material The online version of this article (doi:10.1007/s10584-014-1122-3) contains supplementary material, which is available to authorized users.

M. Petr • L. G. J. Boerboom • A. van der Veen

Faculty of Geo-Information Science and Earth Observation (ITC),

University of Twente, Enschede, Netherlands

L. G. J. Boerboom

e-mail: 1.g.j.boerboom@utwente.nl

A. van der Veen

e-mail: A.vanderVeen@utwente.nl

M. Petr $(\bowtie) \cdot$ D. Ray

Forest Research, Forestry Commission, Northern Research Station,

EH25 9SY Roslin, Great Britain, UK

e-mail: Michal.Petr@forestry.gsi.gov.uk

D. Ray

e-mail: Duncan.Ray@forestry.gsi.gov.uk 
Moreover, this paper demonstrates the value of probabilistic climate projections for an important economic and environmental sector.

\section{Introduction}

Drought has resulted in high forest mortality (Allen et al. 2010; van Mantgem et al. 2009) and has reduced tree productivity in Europe (Ciais et al. 2005). With a projected shift in the seasonal distribution of rainfall, and warmer and drier summers in Britain due to climate change (Murphy et al. 2009) we expect an increase in drought impacts reducing tree growth for many species (Read et al. 2009). However, the inherent uncertainty about climate change and its impacts have been a limiting factor for impact studies (Lindner et al. 2010; Naylor et al. 2007). The need for quantification of climate change uncertainty expressed as probabilities of impacts have been recognized for policy advice and risk management (Kunreuther et al. 2013). Since 2009, subjective probabilities representing climate change uncertainty have become available from the fifth generation UK Climate Projections (UKCP09) (Murphy et al. 2009). In a risk assessment these probabilities for climate variables can represent the likelihood of occurrence of natural hazards like drought. The second part of the risk assessment deals with the vulnerability of a system to the hazard (Turner et al. 2003) such as the response of tree growth to drought.

Few studies have investigated climate change impacts on tree growth in Britain (Broadmeadow et al. 2005; Proe et al. 1996). Impacts on tree growth have been estimated with an empirical non-linear model for Sitka spruce in Scotland (Proe et al. 1996), and with a knowledge-based model for oak, beech, and ash across Britain (Broadmeadow et al. 2005). These models demonstrated inter alia growth rates increase for Sitka spruce between 2.4 and $2.8 \mathrm{~m}^{3} \mathrm{ha}^{-1}$ year $^{-1}$ for each $1{ }^{\circ} \mathrm{C}$ warming, but also variable tree growth depending on the location and the drought index. However, these studies used deterministic climate data - i.e. used a single climate projection, and therefore omitted uncertainty in climate modelling, and offered limited information about climate change impacts over time.

Uncertainty is a salient component of a risk assessment: a process of identification and evaluation of risks (Willows and Connell 2003). Uncertainty, defined as an incomplete understanding of a system to be managed (Brugnach et al. 2008) limits our knowledge about potential drought impacts and its probability of occurrence. Quantified uncertainty handles risk as a combination of the "true" probability of a natural hazard and its impacts (Blaikie 1994). Future risk has been difficult to assess in forestry due to the lack of information about the probability of natural hazards (Gadow 2000). In risk assessments however, analysts deal with two types of uncertainty: epistemic - associated with limited knowledge - and stochastic associated with variability (Suter et al. 1987; Walker et al. 2003). Although it is possible to reduce epistemic uncertainty with new knowledge and a better understanding of the system acquired from new research, additional research cannot reduce stochastic uncertainty (Walker et al. 2003). Fortunately, the UKCP09 climate change projections quantify uncertainty into probabilities allowing development of a new type of risk assessment. Simulation of a large number of ensembles with the Met Office HadCM3 model and twelve international climate models used in the IPCC 4th Assessment Report allowed UKCP09 to quantify subjective probabilities representing uncertainty in modelling and natural climate variability (Murphy et al. 2009). We extend these probabilities to define spatial and temporal uncertainty as a variation in climate over space and over time, respectively. Consequently, quantification of epistemic and stochastic uncertainty into probabilities within the UKP09 projections has enabled us to assess the future drought risk to forests. 
Our main question is how spatial and temporal climate change uncertainty affects the drought risk of tree growth for three major species across Britain. The consequent research objective is to assess drought risk on the public forest estate for the conifer species Sitka spruce (Picea sitchensis) and Scots pine (Pinus sylvestris), and the broadleaf species pedunculate oak (Quercus robur). These species cover 692,000 ha (spruce), 227,000 ha (pine), and 223,000 ha (oak pedunculate and sessile) from all woodlands, from which we analysed $59 \%$ (400,700 ha) on the public forest estate (Forestry Commission 2012). For the risk assessment we used climate data from the UKCP09 Weather Generator (Jones et al. 2009) for the baseline (19611990 ) and the seven future 30 year time periods representing the 2020 s to the 2080 s. Drought conditions correspond to moisture deficit, when potential-evapotranspiration is higher than precipitation. To calculate drought's probability we used probabilistic climate data and to calculate tree vulnerability represented by predicted yield classes (YC) we used the Ecological Site Classification (ESC) knowledge-based model (Broadmeadow et al. 2005). Yield class represents the maximum achievable average rate of volume increment. The total potential yield class change is our drought risk measure calculated as accumulated multiplications of different degrees of drought with associated vulnerabilities, following a risk calculation method by Smith (1992). Only drought was evaluated without considering, for example, edaphic factors of soil wetness and fertility important for tree growth due to the lack of data. Finally, we stratified forests into lowland and upland sites because of different rates of tree growth in different climate zones for which we spatially and randomly sampled climate data.

\subsection{Risk assessment}

For our drought risk assessment we followed a "top-down" approach introduced by Dessai and Hulme (2004), which proposed first to estimate the future climate with climate models and then to assess the physical vulnerability, in our case for trees, to known baseline climate conditions with impact models. Our innovation in the risk assessment is the combination of different future drought subjective probabilities from UKCP09 and tree vulnerability derived from the Ecological Site Classification model.

The first part of our risk assessment is hazard, which has a certain probability. The complexity of estimating the probability of the future climatic conditions has been recognized in many studies (Dessai and Hulme 2004; Mastrandrea and Schneider 2004; Schneider 2001). Although we cannot have true probabilities, i.e. measured frequencies, as these studies suggested we can calculate subjective or conditional probabilities with a Bayesian probability framework (Dessai and Hulme 2004; Schneider 2001). This Bayesian approach led to the probabilistic UKCP09 climate change projections, which offer subjective probabilities of climate variables within the current knowledge bounds of the climate system (Murphy et al. 2009). Data from the UKCP09 projections have allowed us to create drought probability curves as empirical cumulative distribution functions (ECDF) using only moisture deficit values. The ECDF curves represent drought probabilities for the future time periods, for a range of emissions scenarios, and for different locations across Britain. To assess and compare drought risk across different plausible futures we used the available SRES emissions scenarios of B1, A1B, and A1FI (Nakicenovic et al. 2000).

The second part of our risk assessment is physical vulnerability, which defined how trees respond to external factors such as drought. One approach for defining vulnerability is to choose a critical threshold as a deterministic value (Jones 2001) which has been used for example in a risk assessment of rice production (Naylor et al. 2007). Its limitation is in evaluating and precisely defining the critical value while omitting responses of the system to other degrees of exposure. By contrast, the second approach uses the range of possible impacts 
known as loss functions or ratios (Kerns and Ager 2007) or vulnerability curves (PapathomaKöhle et al. 2012). These curves define the response of the system to degrees of impact, in our case tree growth across the range of drought levels. We developed vulnerability curves of the growth response of three tree species to different levels of drought using observed drought conditions across Britain in the baseline climate (1961-1990). These curves describe the relationship between drought - represented by moisture deficit index - and predicted stand yield class, where yield predictions were used from the Ecological Site Classification model (Broadmeadow et al. 2005). We assumed the same relationship between the moisture deficit index and the stand yield class in the baseline will persist into the future, as Williams et al. (2010) have shown in the US.

\section{Material and methods}

\subsection{Data collection}

Baseline climate (1961-1990) data were available from the Ecological Site Classification (ESC) model and the UKCP09. From the ESC model we used averages of annual accumulated temperature (AT - sum of day degrees $>5{ }^{\circ} \mathrm{C}$ ) and moisture deficit (MD - drought index) previously downscaled to $250 \mathrm{~m}$ across Britain. ESC originally used MD values calculated from the Met Office MORECS dataset (Thompson et al. 1981) and AT values from the Climatic Research Unit. The UKCP09 climate projections (Murphy et al. 2009) with the Weather Generator (WG) simulated climate data at $5 \mathrm{~km}$ spatial resolution (Jones et al. 2009). For the calculation of moisture deficit index we used precipitation [mm] and potential evapotranspiration [mm/day] for grass (PET); with PET calculated by the Penman-Monteith method (see (Jones et al. 2009)) which provides more accurate drought estimates than some temperature based PET methods (Sheffield et al. 2012). The climate projections were available for three greenhouse gas emissions scenarios equivalent to the IPCC SRES scenarios: low (B1), medium (A1B), and high (A1FI); and seven overlapping 30 year time periods starting from the 2020s (2010-2039) until the 2080s (2070-2099), in addition to the baseline (19611990 ) period. We randomly sampled 100 runs from the 10,000 available model variant runs for each emissions scenario and time period to obtain probabilistic data. The structure of each climate data output was 100 runs across 30 years of daily values.

We designed a stratified random sampling experiment to spatially sample locations across Britain with different climatic conditions. We randomly sampled one Weather Generator site including at least one patch of public forest within two strata: (i) $100 \mathrm{~km}$ regular square grid cells from the British National Grid, and (ii) the lowlands and uplands. This sampling allowed an accurate depiction of the spatial changes in the stand yield class for spruce, pine, and oak. There was a logistic constraint in gathering large volumes of climate data from the weather generator hence we limited our selection to up to two weather generator sites per one $100 \mathrm{~km}$ grid cell. We believe that weather generator sites at $5 \times 5 \mathrm{~km}$ spatial resolution are representative of both lowland and upland forested areas within $100 \mathrm{~km}$ grid cells. Therefore, we present outputs at a resolution of the $100 \mathrm{~km}$ grid. We used twenty-nine $100 \mathrm{~km}$ grid cells each containing at least $25 \%$ of landmass area, i.e. less than $75 \%$ of water area. The lowlands and the uplands were delineated by climate zones using AT and MD (Clark et al. 2010). The lowlands consist of Warm Dry and Warm Moist climate zones and the uplands consist of Warm Wet, Cool Wet, and Cool Moist climate zones defined by the ESC model (Fig. S1). Using this definition, our northern upland areas are at the lower elevation than our southern upland areas in Great Britain. The spatial extent of the uplands and the lowlands in Britain was 
similar to Clark et al. (2010). Our final sample consisted of $28 \mathrm{WG}$ sites in the lowlands and 23 WG sites in the uplands (Fig. S3 and Table S1).

\subsection{Data analysis}

\subsubsection{Hazard assessment}

For the hazard assessment, we calculated a single annual climatic moisture deficit index (Zimmermann and Kienast 1999) as accumulation of positive monthly MD values, by subtracting monthly precipitation values from monthly PET values. We developed a Python script to automate calculation of MD values. Due to the differences between MD values used in the ESC model and those calculated from the weather generator in the baseline period, we developed a moisture index adjustment linear regression model using median MD values (see Supplementary data). This linear regression model was parameterised using 100 runs and 30 years of WG data and $400 \mathrm{MD}$ values from the ESC model (at $250 \mathrm{~m}$ resolution) covering all $51 \mathrm{WG}$ sites. We adjusted WG MD values within the regression model limits when values were below $205 \mathrm{~mm}$. Next, we computed MD values for all WG sites 3,000 times - consisting of 100 runs for each 30 years of MD values - for the baseline and seven time periods, and for three emissions scenarios, similar to the approach by Oven et al. (2012). Finally, we constructed an empirical cumulative distribution function (ECDF) from 3,000 MD values to estimate MD subjective probabilities.

\subsubsection{Vulnerability assessment}

For the vulnerability assessment, we created vulnerability curves for spruce, pine, and oak by combining the calculated potential stand yield class and the ESC moisture deficit in the baseline climate, which described the growth response of a tree to drought conditions (Fig. S4). Using MD and accumulated temperature values we calculated the stand yield class as a multiplication of maximum potential achievable yield class in Britain ( spruce $=28$, pine $=$ 16 , and oak $\left.=8\left(\mathrm{~m}^{3} \mathrm{ha}^{-1} \mathrm{year}^{-1}\right)\right)$ and adjustment factors for AT and MD based on the response function of each tree species using the ESC model at $250 \mathrm{~m}$ spatial resolution. In this calculation for the baseline climate, we used warmth and moisture deficit to get a realistic estimation of the stand yield class in British conditions. Next, we plotted the 3.545 million points - each at $250 \mathrm{~m}$ spatial resolution - for the estimated stand yield classes and MD values and calculated average and standard deviation for each stand yield class across $10 \mathrm{~mm}$ MD discrete intervals, and with error bars showing standard deviations representing the variability caused by AT values (see Fig. S4). In the final step we fitted a cubic function between average stand yield classes and moisture deficit values across the $10 \mathrm{~mm}$ MD discrete intervals for spruce, pine, and oak to obtain vulnerability equations for each tree in the baseline climate (See Dataset S2).

\subsubsection{Risk assessment}

The risk assessment combines hazard and vulnerability, for which we calculated drought risk as a multiplication of drought level probabilities and tree species vulnerabilities. We extracted moisture deficit probabilities from the 100 equally distributed bins - discrete class intervals across the empirical cumulative distribution function curves, for the baseline and each emissions scenario in the future time periods. The probability of each discrete class was defined by subtracting the lower from the higher partial probability from the two class 
boundaries. For a reference point in the baseline we calculated the potential stand yield class for the median MD value for each WG site using the stand yield class estimation equation. To calculate vulnerability, we computed the stand yield class using the stand yield class estimation equation and assigned it to each MD class centroid. The estimated future stand yield class was subtracted from the baseline stand yield class - reference point - which gave us the stand yield class change for each MD class. We calculated partial risk values for each of the $100 \mathrm{MD}$ classes by multiplying the probability of the MD class with the corresponding stand yield class change value. The final total potential stand yield class change, either positive or negative, from the baseline into the future was calculated as a sum of the 100 partial risk values (more details in Supplementary data). In addition, we calculated the future stand yield class as a relative change from the baseline stand yield class. The processing steps for the drought risk assessment are in the R script (Dataset S1) and the drought risk outputs for all WG sites are in (Dataset S2).

\subsubsection{Forest production estimation}

To assess the impact of drought risk, we calculated the total potential forest production of the public forest estate, now and in to the future, for each $100 \mathrm{~km}$ grid cell, and separately for the lowlands and uplands. We used the public forest estate dataset (http://www.forestry.gov.uk/ datadownload) including information about tree species, stand area, and yield class, to calculate the baseline forest production $\left(\mathrm{m}^{3}\right.$ year $\left.^{-1}\right)$ as a multiplication of the yield class by the stand area. For the future, we calculated the potential stand yield class as a multiplication of the baseline stand yield class with the relative stand yield class change value for lowland or upland sites attributed to each $100 \mathrm{~km}$ grid cell. The future forest production was then calculated as the product of the adjusted future stand yield class value by the current stand area. It was not possible to validate the stand yield class for each species due to the lack of observed data, therefore our calculation of future forest production is conservative with using relative stand yield class change values.

We performed all analyses in R statistical software (R Development Core Team 2012) and used the lattice package for visualization (Sarkar 2008).

\section{Results}

Drought risk of the future potential stand yield class for all 28 lowland and 23 upland sites using the Weather Generator squares is summarized in Fig. 1. As the stand rotation length for spruce is around 50 years in Britain, we selected the 2050s from the seven time periods in Fig. 1. For instance, in the lowlands and for the medium A1B emissions scenario we see a greater reduction of the median stand yield class for spruce from 22.3 to $12.4 \mathrm{~m}^{3} \mathrm{ha}^{-1}$ year ${ }^{-1}$ and a smaller reduction for pine and oak from 15.7 to $13.7 \mathrm{~m}^{3} \mathrm{ha}^{-1}$ year ${ }^{-1}$ and 7.3 to $5.7 \mathrm{~m}^{3} \mathrm{ha}^{-1}$ year ${ }^{-1}$, respectively. On the other hand, in the uplands and for the same emissions scenario we see a smaller reduction in the median stand yield class for spruce from 23.7 to $20.4 \mathrm{~m}^{3} \mathrm{ha}^{-1}$ year $^{-1}$ and an increase for pine and oak from 14.3 to $15.1 \mathrm{~m}^{3} \mathrm{ha}^{-1}$ year ${ }^{-1}$ and 5.2 to $6.5 \mathrm{~m}^{3} \mathrm{ha}^{-1}$ year ${ }^{-1}$, respectively. In the future, drought conditions may cause a larger reduction in the stand yield class in the lowlands and a smaller reduction or even an increase in the uplands, making the uplands more suitable for the future forest production under all emissions scenarios.

From the summary statistics of the predicted potential stand yield classes we turn to the spatial and temporal drought risk assessment within $100 \mathrm{~km}$ grid cells. Each grid cell 


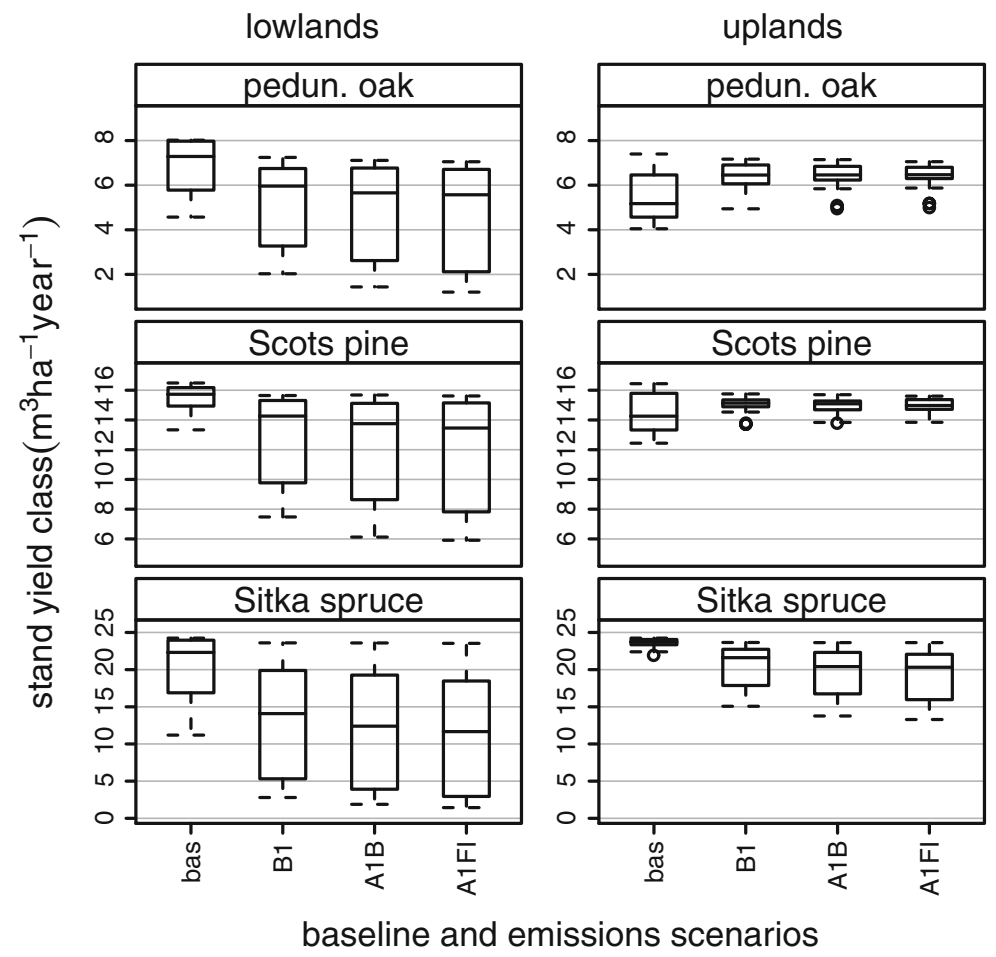

Fig. 1 Potential stand yield classes for Sitka spruce, Scots pine, and pedunculate oak in the 2050s for emissions scenarios (B1, A1B, A1FI) and the baseline "bas" (1961-1990), and for lowland $(n=28)$ and upland $(n=23)$ sites

represents results for one weather generator square for forests either in the lowlands or uplands. The drought risk across Britain will lead to a reduction of the stand yield class depending on the species, emissions scenario, and the location. In the lowlands, drought impacts reduced the stand yield class by up to $94 \%$ in south-east Britain, whereas the drought conditions had a positive impact on yield class with an increase up to $42 \%$ in west and north-west Britain across three emissions scenarios in the 2050s and 2080s (Fig. 2). In north-east Britain, on higher spruce yield class sites in the baseline, a smaller predicted stand yield class reduction was predicted until the $2080 \mathrm{~s}$, resulting in more resilient spruce stands to drought than in other parts of Britain, except for the west. Conversely, on higher pine and oak yield class sites in the baseline period in east and south-east Britain, predicted higher stand yield class reduction making such stands less resilient to drought than in other locations.

In the uplands, the drought impacts reduced the potential stand yield class by up to $64 \%$ in the east of Britain. Drought conditions may be less extreme in the west of Britain, and our results show an increase in the stand yield class by up to $56 \%$ across the three emissions scenarios in both the 2050s and 2080s (Fig. 3). The higher future decline in spruce yield class will be on sites with current estimated high yield, making stands less resilient to drought in the future. By contrast, increased pine and oak stand yield class, especially on sites with current low yield, suggests these stands will be more resilient to drought in the future. Due to the lower pine and oak yield class values in the baseline, the predicted small relative increase in yield class will be small in absolute 

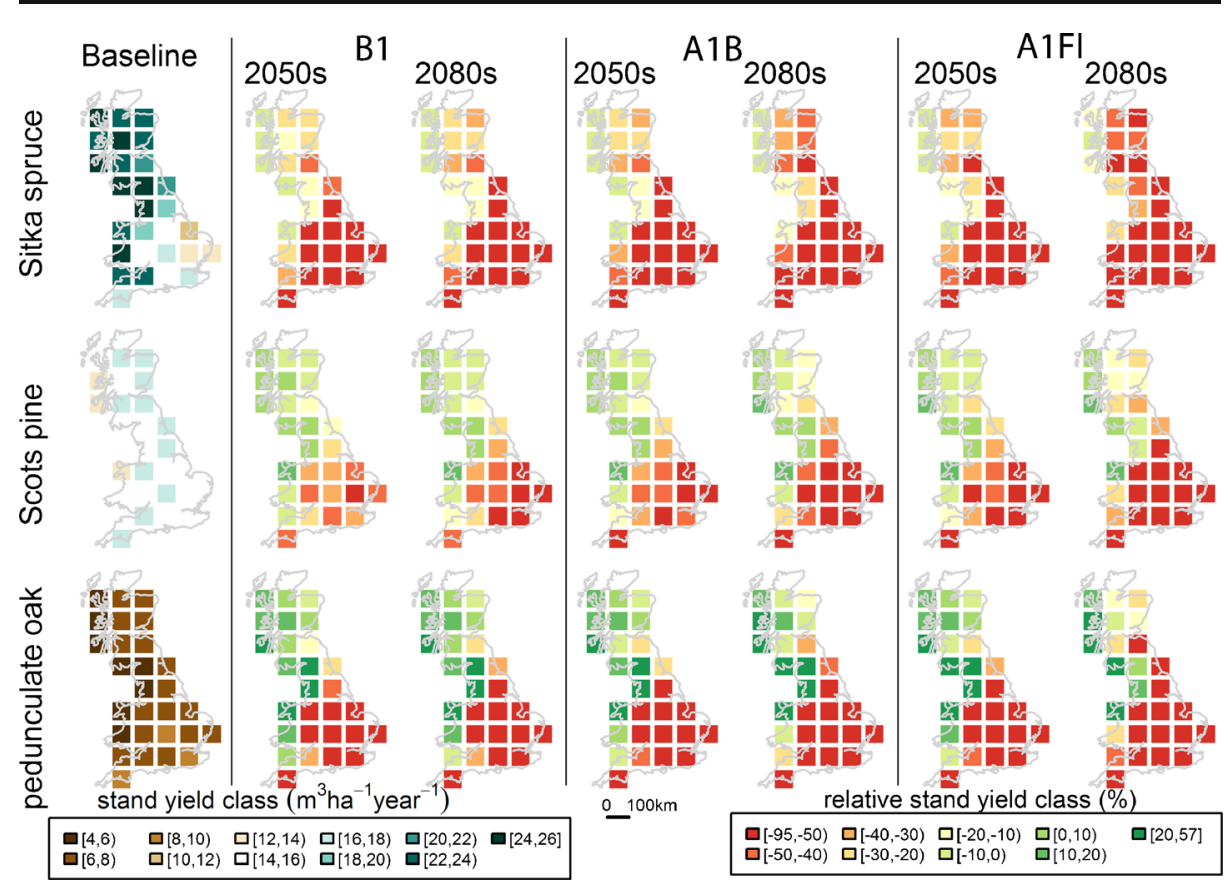

Fig. 2 Changes in the lowlands of relative stand yield classes (\%) from the baseline to the future (2050s and 2080s) due to drought conditions for Sitka spruce, Scots pine, and pedunculate oak for emissions scenarios (B1, $\mathrm{A} 1 \mathrm{~B}, \mathrm{~A} 1 \mathrm{FI})$. Red indicates a reduction and green indicates an increase in the predicted stand yield class

growth terms. The predicted relative yield class changes for all species, for the seven time periods from the 2020 s to the 2080 s, and for both the lowlands and uplands are shown in (Fig. S6 - Fig. S8).

We extrapolated the projected drought effects to predict the potential future forest production for the public forest estate in Britain. The total potential production for spruce, pine, and oak stands is predicted to decrease over the next 80 years. The biggest negative drought effect on forest production was for the A1FI emissions scenario in the 2080s, which is not surprising as A1FI scenario estimates the greatest temperature increase resulting in drier climatic conditions. In the lowlands, the biggest reduction of $74 \%$ in relative forest production from the baseline was for oak (Fig. 4). In absolute terms, the largest reduction in forest production of $570 * 10^{3}\left(\mathrm{~m}^{3}\right.$ year $\left.^{-1}\right)$ (equivalent to $39 \%$ reduction) was for spruce. In the uplands, on the other hand, the largest reduction in forest production in absolute terms was $987 * 10^{3}$ $\left(\mathrm{m}^{3}\right.$ year $^{-1}$ ) (equivalent to $35 \%$ reduction) for spruce, but there was also an $18 \%$ increase for oak in the A1B emissions scenario in the 2060s. Due to higher forest production in the uplands, the largest absolute reduction of $987 * 10^{3}\left(\mathrm{~m}^{3}\right.$ year $\left.{ }^{-1}\right)$ was for spruce, almost twice the production than in the lowlands. The combined total loss in forest production for stands of spruce, pine, and oak across the public forest estate was predicted to be larger in the uplands ( 515 to $1,028^{*} 10^{3} \mathrm{~m}^{3}$ year $^{-1}$ ) than in the lowlands (432 to $729 * 10^{3} \mathrm{~m}^{3}$ year ${ }^{-1}$ ) for the B1 and A1FI emissions scenarios in the 2080s. The reason for greater future forest production losses in the uplands is mainly due to higher forest productivity over a larger forest area, despite being less affected by drought and having better climatic conditions for growth than in the lowlands. For more details on baseline forest production within $100 \mathrm{~km}$ grid cells for spruce, pine, and oak see maps (Fig. S5). 


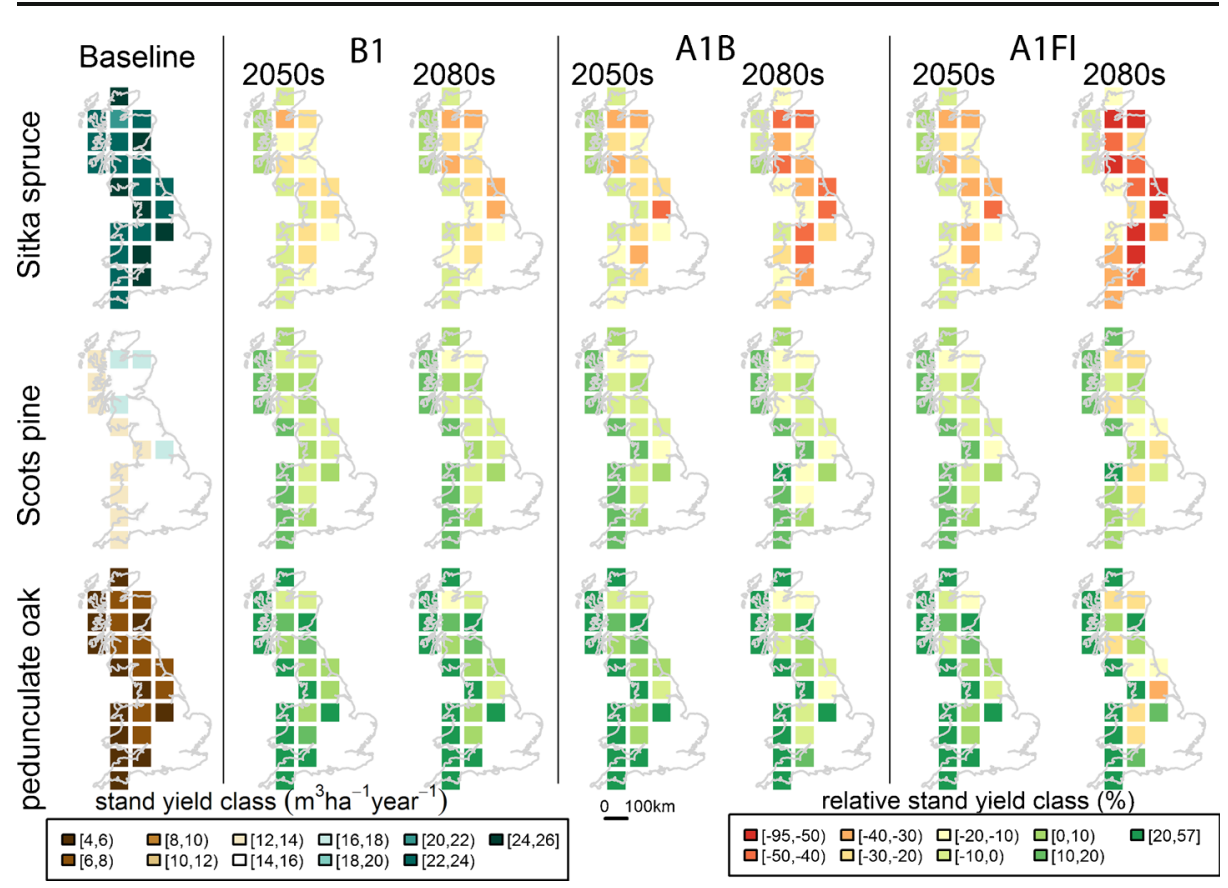

Fig. 3 Changes in the uplands of relative stand yield classes (\%) from the baseline to the future (2050s and 2080s) due to drought conditions for Sitka spruce, Scots pine and pedunculate oak for emissions scenarios (B1, A1B, A1FI). Red indicates a reduction and green indicates an increase in the predicted stand yield class

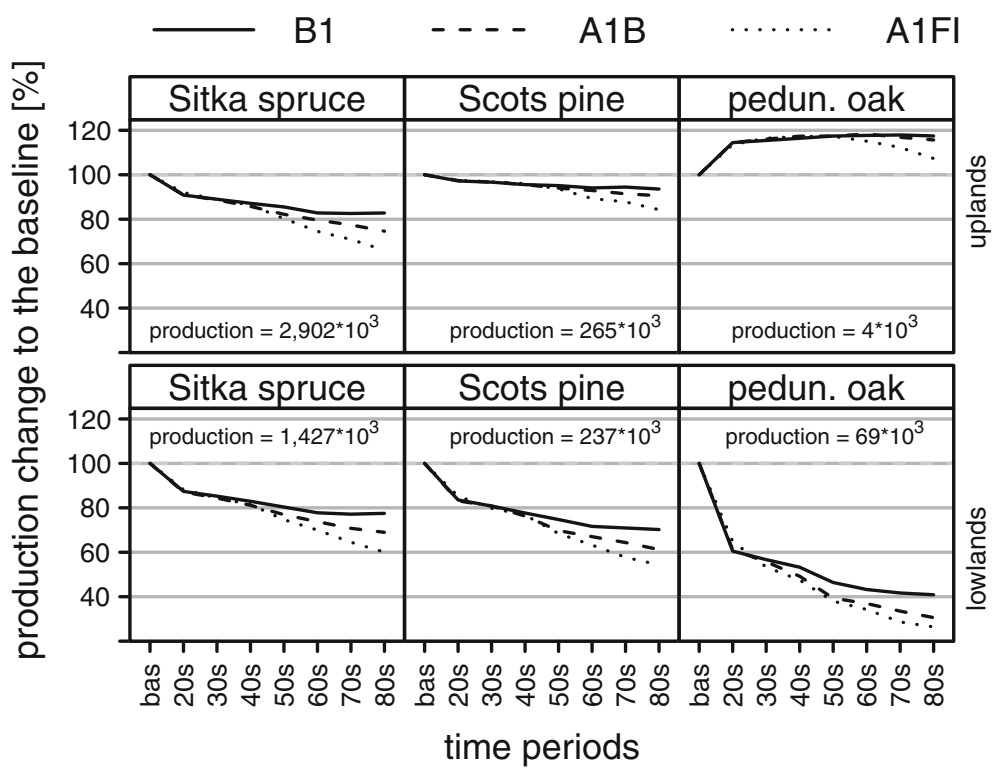

Fig. 4 Relative changes (\%) in the total potential forest production for spruce, pine, and oak forests of the British public forest estate in the lowlands (143 $500 \mathrm{ha}$ ) and the uplands (257 $000 \mathrm{ha})$ from the baseline "bas" until the 2080s for three emissions scenarios (B1, A1B, A1FI) 


\section{Discussion and conclusions}

Our drought risk assessment reveals a high likelihood mainly of future potential reduction in tree growth for the three major species in Britain. The assessment does not consider among others soil water content and soil available water capacity at each site, which may reduce the impacts of drought on tree growth, and so we describe our findings as a potential reduction in tree growth. For example, increased drought conditions and consequent drier soils have caused higher tree mortality on Pinus edulis in south-western US (Breshears et al. 2005) on drier sites following a very severe drought in 2002-2003.

Depending on location, time period, and the future emissions scenario, increased drought conditions will exert different impacts on the total potential stand yield class for spruce, pine, and oak. With respect to location, we predict growth reduction of up to $94 \%$ for total stand yield class in the lowlands and as much as a $64 \%$ reduction in the uplands mainly across south-east and east Britain in the 2080s (Figs. 2 and 3). In addition, our results demonstrate spruce being more drought sensitive compared with pine and oak, with a median stand yield class reduction of $44 \%$ from the baseline in the lowlands in the 2050s (Fig. 1). For oak, our results show a $13 \%$ reduction of the median stand yield class in the $2050 \mathrm{~s}$ (Fig. 1) similar to a study (Broadmeadow et al. 2005) which incorporated additional limiting factors to tree growth and used previous non-probabilistic UK climate change projections (UKCIP2002). A study of drought impacts in the US showed a $25 \%$ reduction in yield from pine plantations by 2100 (Battles et al. 2007). With respect to time periods, we found a large yield class reduction of up to $89 \%$ in the 2050 s and even higher reductions up to $94 \%$ by the 2080s. In contrast, previous studies mostly evaluated impacts only for one time period e.g. 2050-2099 (Williams et al. 2010) or over three time periods (Battles et al. 2007). With respect to the emissions scenarios, our results emphasise increased changes in the drought risk particularly after the 2050s in accordance with higher emissions scenario uncertainty (Meehl et al. 2007; Murphy et al. 2009). We conclude that our new spatial and temporal assessment of drought risk across Britain will provide valuable forest management information for medium to long-term climate change adaptation.

We predicted potential forest production losses due to drought conditions on the public forest estate, considering forest location, tree area of forest, tree species, and changes in potential tree growth. However, the predicted production volumes omitted the effects of the changing species age distribution. Spruce, the species with the largest forest area and being more sensitive to drought, contributed to combined forest production losses by $78 \%$ and $96 \%$, respectively, resulting in overall forest production loss of $42 \%$ in the lowlands and $32 \%$ in the uplands from the baseline to the 2080s for the A1FI emissions scenario. This finding is similar to the evidence from the US (Williams et al. 2010), which reported mean tree growth reductions of $34 \%$ in ponderosa pine due to a projected warmer and drier climate for the A1B emissions scenario between 2050-2099, as well as to the estimated $30 \%$ reduction in forest productivity in Europe in 2003 due to the observed extreme heat wave and drought (Ciais et al. 2005). Besides losses in forest production, drought can also trigger higher tree mortality (Allen et al. 2010; van Mantgem et al. 2009) and reduce trees productivity under elevated $\mathrm{CO}_{2}$ levels (Warren et al. 2011), not investigated in this study. Moreover, predicted drought impacts will result in more vulnerable forests in the lowlands and uplands, and this concurs with the reduction of species range especially for spruce by 2100 (Hanewinkel et al. 2012).

In our drought risk assessment the use of probabilistic climate data with the Ecological Site Classification model allowed the investigation of spatial and temporal climate change 
uncertainty, and epistemic uncertainty or a limited knowledge relating to tree vulnerability and climate projections. We are aware that the probabilistic climate change projections can give an impression of "false" drought certainty. In fact, complete certainty is not achievable for an open system such as climate change (Pielke 2001) since uncertainty in the form of recognized or total ignorance remains (Walker et al. 2003). However, the probabilistic climate data captures some of the recognized uncertainty from climate models within the current knowledge bounds of the climate system. The degree of climate change uncertainty varies spatially and increases through each decade up to the 2080s due to the different agreements about climate parameters within climate models, as study by Mbogga et al. (2010) has also shown for aspen habitat distribution. This uncertainty also affects drought risk, which in most cases reduces the total stand yield class (Figs. 2 and 3) and forest production (Fig. 4) across Britain. Different futures driven by plausible emissions scenarios also represent uncertainty (Walker et al. 2003). At a site level, we found diverging drought risk estimates across emissions scenarios after the 2050s (Fig. S6 - Fig. S8) as well as at the national level (Fig. 4) which is supported by UKCP09 projections (Murphy et al. 2009) and global warming projections (Meehl et al. 2007). Epistemic uncertainty as a limited knowledge about tree species response to extreme drought remains high compared with better knowledge about average drought impacts in British conditions. A recent study by Zimmermann et al. (2009) highlighted the need for information about climate extremes that can improve our understanding of species limits and support robust estimations of species distributions. Extreme droughts are more damaging, affect forest productivity (Ciais et al. 2005), and are projected to become more frequent in the future (Meehl and Tebaldi 2004). Uncertainty still remains a constraint for risk assessments but its quantification as a subjective probability provides a better understanding of drought risk.

The findings of this research can help forest managers at local and national levels to identify and reduce drought risk to sustain timber production over the next 80 years. At a local level, forest managers can incorporate information about trends from drought risk outputs at $5 \mathrm{~km}$ spatial resolution into medium to long-term forest plans supporting climate change adaptation measures such as species choice. These measures are mostly applied at a local level, where a great need for risk and vulnerability assessments exists (Williams et al. 2010). At the national level, our results enable forest managers to identify drought risk hotspots, using modelled losses and gains of the potential stand yield class. Such a strategic application of the analysis will help forest managers decide which species, when, and where - in the lowlands or in the uplands - they may adapt forest management or expand woodlands with appropriate species with more confidence. Furthermore, with respect to emissions scenarios, forest managers can make similar decisions to the drought over the next 40 years, since drought risk for scenarios diverges after the 2050s. Additionally, an aspiration exists to expand the woodland area in each of the devolved countries of Britain, for example, in Scotland from 17 to $25 \%$ by the second half of 21 st century (Forestry Commission Scotland 2006). Forest managers may establish new forests preferably on upland sites which tend to be less drought sensitive compared with lowlands sites, as our findings suggest. However, they must still consider factors such as forest site conditions.

The combination of a tree's vulnerability to drought and the drought probability with probabilistic climate data offer a new and robust way to assess drought risk across Britain. Probabilistic data reduce the epistemic uncertainty associated with drought risk, in contrast to traditional single based climate models, but uncertainty still remains a challenge for the future risk assessments. Future research should focus on a better understanding of tree species response to extreme drought conditions; and on a drought risk assessment for other tree species that may provide new alternatives for future sustainable forestry. Overall, our findings 
show that the west and north-west part of the Britain is much less sensitive to drought, and hence forests can deliver more ecosystem goods and services and forest expansion should be targeted in these areas.

Acknowledgments We thank Forest Research staff for advices with the data analysis, and James Morison and Chris Quine for comments to the manuscript. This research has been sponsored by the ForeStClim project "Transnational Forestry Management Strategies in Response to Regional Climate Change Impacts" in the INTERREG IVB programme in North-West Europe of the European Regional Development Fund (ERDF). Project No. 003A. We are grateful to the editor and two reviewers for their valuable and constructive comments on an earlier version of the paper.

Open Access This article is distributed under the terms of the Creative Commons Attribution License which permits any use, distribution, and reproduction in any medium, provided the original author(s) and the source are credited.

\section{References}

Allen CD, Macalady AK, Chenchouni H, Bachelet D, McDowell N, Vennetier M, Kitzberger T, Rigling A, Breshears DD, Hogg (Ted) EH (2010) A global overview of drought and heat-induced tree mortality reveals emerging climate change risks for forests. For Ecol Manage 259:660-684

Battles JJ, Robards T, Das A, Waring K, Gilless JK, Biging G, Schurr F (2007) Climate change impacts on forest growth and tree mortality: a data-driven modeling study in the mixed-conifer forest of the Sierra Nevada. Calif Clim Change 87:193-213

Blaikie PM (1994) At risk: natural hazards, people's vulnerability, and disasters. Routledge, London

Breshears DD, Cobb NS, Rich PM, Price KP, Allen CD, Balice RG, Romme WH, Kastens JH, Floyd ML, Belnap J, Anderson JJ, Myers OB, Meyer CW (2005) Regional vegetation die-off in response to globalchange-type drought. Proc Natl Acad Sci U S A 102:15144-15148

Broadmeadow MSJ, Ray D, Samuel CJA (2005) Climate change and the future for broadleaved tree species in Britain. Forestry 78:145-161

Brugnach M, Dewulf A, Pahl-Wostl C, Taillieu T (2008) Toward a relational concept of uncertainty: about knowing too little, knowing too differently, and accepting not to know. Ecol Soc 13:16

Ciais P, Reichstein M, Viovy N, Granier A, Ogee J, Allard V, Aubinet M, Buchmann N, Bernhofer C, Carrara A, Chevallier F, De Noblet N, Friend AD, Friedlingstein P, Grunwald T, Heinesch B, Keronen P, Knohl A, Krinner G, Loustau D, Manca G, Matteucci G, Miglietta F, Ourcival JM, Papale D, Pilegaard K, Rambal S, Seufert G, Soussana JF, Sanz MJ, Schulze ED, Vesala T, Valentini R (2005) Europe-wide reduction in primary productivity caused by the heat and drought in 2003. Nature 437:529-533

Clark J, Orr H, Freer J, House J, Smith P, Freeman C (2010) Assessment of projected changes in upland environments using simple climatic indices. Clim Res 45:87-104

Dessai S, Hulme M (2004) Does climate adaptation policy need probabilities? Clim Policy 4:107-128

Forestry Commission (2012) Forestry statistics. Edinburgh

Forestry Commission Scotland (2006) The Scottish forestry strategy. Edinburgh

Gadow KV (2000) Evaluating risk in forest planning models. Silva Fenn 34:181-191

Hanewinkel M, Cullmann DA, Schelhaas M-J, Nabuurs G-J, Zimmermann NE (2012) Climate change may cause severe loss in the economic value of European forest land. Nat Clim Chang 2:1-5

Jones RN (2001) An environmental risk assessment/management framework for climate change impact assessments. Nat Hazards 23:197-230

Jones PD, Kilsby CG, Harpham C, Glenis V, Burton A (2009) UK climate projections science report: projections of future daily climate for the UK from the weather generator

Kerns BK, Ager A (2007) Risk assessment for biodiversity conservation planning in Pacific Northwest forests. For Ecol Manage 246:38-44

Kunreuther H, Heal G, Allen M, Edenhofer O, Field CB, Yohe G (2013) Risk management and climate change. Nat Clim Chang $0-5$

Lindner M, Maroschek M, Netherer S, Kremer A, Barbati A, Garcia-Gonzalo J, Seidl R, Delzon S, Corona P, Kolström M, Lexer MJ, Marchetti M (2010) Climate change impacts, adaptive capacity, and vulnerability of European forest ecosystems. For Ecol Manage 259:698-709 
Mastrandrea MD, Schneider SH (2004) Probabilistic integrated assessment of "dangerous" climate change. Science 304:571-575

Mbogga MS, Wang X, Hamann A (2010) Bioclimate envelope model predictions for natural resource management: dealing with uncertainty. J Appl Ecol 47:731-740

Meehl GA, Tebaldi C (2004) More intense, more frequent, and longer lasting heat waves in the 21st century. Science 305:994-997

Meehl GA, Stocker TF, Collins WD, Friedlingstein P, Gaye AT, Gregory JM, Kitoh A, Knutti R, Murphy JM, Noda A, Raper SCB, Watterson IG, Weaver AJ, Zhao ZC (2007) Global Climate Projections. In: Climate Change 2007: The Physical Science Basis. Contribution of Working Group I to the Fourth Assessment Report of the Intergovernmental Panel on Climate Change, D Qin M Manning Z Chen M Marquis K Averyt M Tignor and HL Miller New York Cambridge University Press pp, Climate change 2007. Cambridge University Press, Cambridge

Murphy JM, Sexton DMH, Jenkins GJ, Booth BBB, Brown CC, Clark RT, Collins M, Harris GR, Kendon EJ, Betts RA, Brown SJ, Humphrey KA, McCarthy MP, McDonald RE, Stephens A, Wallace C, Warren R, Wilby R, JM (2009) UK Climate Projections Science Report: Climate change projections. Met Office Hadley Centre, Exeter, UK

Nakicenovic N, Alcamo J, Davis G (2000) Special Report on Emissions Scenarios, Working Group III of the Intergovernmental Panel on Climate Change IPCC. Cambridge University Press

Naylor RL, Battisti DS, Vimont DJ, Falcon WP, Burke MB (2007) Assessing risks of climate variability and climate change for Indonesian rice agriculture. Proc Natl Acad Sci U S A 104:7752-7757

Oven KJ, Curtis SE, Reaney S, Riva M, Stewart MG, Ohlemüller R, Dunn CE, Nodwell S, Dominelli L, Holden R (2012) Climate change and health and social care: Defining future hazard, vulnerability and risk for infrastructure systems supporting older people's health care in England. Appl Geogr 33:16-24

Papathoma-Köhle M, Keiler M, Totschnig R, Glade T (2012) Improvement of vulnerability curves using data from extreme events: debris flow event in South Tyrol. Nat Hazards 64(3):2083-2105

Pielke RJ (2001) Room for doubt. Nature 410, 2001

Proe MF, Allison SM, Matthews KB (1996) Assessment of the impact of climate change on the growth of Sitka spruce in Scotland. Can J For Res 26:1914-1921

R Development Core Team (2012) R: a Language and Environment for Statistical Computing

Read DJ, Freer-Smith PH, Morison JIL, Hanley N, West CC, Snowdon P (2009) Combating climate change - a role for UK forests. An assessment of the potential of the UK's trees and woodlands to mitigate and adapt to climate change. The Stationary Office, Edinburgh

Sarkar D (2008) Lattice: multivariate data visualization with R, Use R. Springer, New York

Schneider SH (2001) What is "dangerous" climate change? Nature 411:17-19

Sheffield J, Wood EF, Roderick ML (2012) Little change in global drought over the past 60 years. Nature 491: $435-438$

Smith K (1992) Environmental hazards: assessing risk and reducing disaster. Routledge, London

Suter GW, Barnthouse LW, O'Neill RV (1987) Treatment of risk in environmental impact assessment. Environ Manage 11:295-303

Thompson N, Barrie IA, Ayles M (1981) The meteorological office rainfall and evaporation calculation system: MORECS (July 1981). Hydrol Memo N45

Turner BL, Kasperson RE, Matson PA, McCarthy JJ, Corell RW, Christensen L, Eckley N, Kasperson JX, Luers A, Martello ML, Polsky C, Pulsipher A, Schiller A (2003) A framework for vulnerability analysis in sustainability science. Proc Natl Acad Sci U S A 100:8074-8079

Van Mantgem PJ, Stephenson NL, Byrne JC, Daniels LD, Franklin JF, Fulé PZ, Harmon ME, Larson AJ, Smith JM, Taylor AH, Veblen TT (2009) Widespread increase of tree mortality rates in the western United States. Science 323:521-524

Walker WE, Harremoes P, Rotmans J, van der Sluijs JP, van Asselt MBA, Janssen P, von Krauss MPK (2003) Defining Uncertainty: A Conceptual Basis for Uncertainty Management in Model-Based Decision Support. Integr Assess 4:5-17

Warren JM, Norby RJ, Wullschleger SD (2011) Elevated CO2 enhances leaf senescence during extreme drought in a temperate forest. Tree Physiol 31:117-130

Williams PA, Allen CD, Millar CI, Swetnam TW, Michaelsen J, Still CJ, Leavitt SW (2010) Forest responses to increasing aridity and warmth in the southwestern United States. Proc Natl Acad Sci U S A 107:2128921294

Willows RI, Connell RK (2003) Climate adaptation: risk, uncertainty and decision-making. UKCIP, Oxford

Zimmermann NE, Kienast F (1999) Predictive mapping of alpine grasslands in Switzerland: Species versus community approach. J Veg Sci 10:469-482

Zimmermann NE, Yoccoz NG, Edwards TC, Meier ES, Thuiller W, Guisan A, Schmatz DR, Pearman PB (2009) Climatic extremes improve predictions of spatial patterns of tree species. Proc Natl Acad Sci U S A 106(Suppl):19723-19728 